\title{
In vitro fermentation of diets incorporating carob pulp using inoculum from rabbit caecum
}

\author{
A. Gasmi-Boubaker ${ }^{1 \#}$, M.R. Mosquera-Losada ${ }^{2}$ \& B. Boubaker ${ }^{3}$ \\ ${ }^{1}$ National Institute of Agronomy of Tunisia, Tunisia \\ ${ }^{2}$ University of Santiago de Compostela, Lugo, Spain \\ ${ }^{3}$ High School of Food Industry, Tunisia
}

(Received 7 August 2012; Accepted 2 February2013; First published online 6 April 2013)

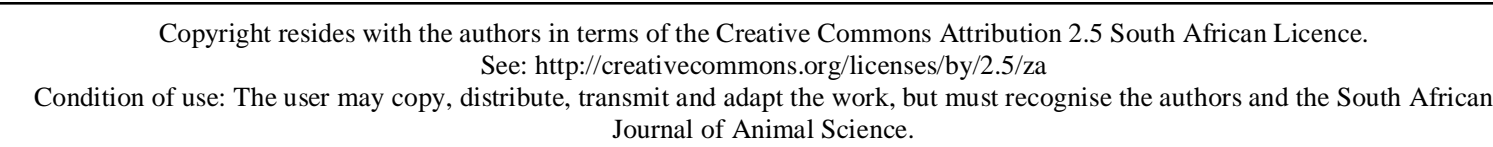

\begin{abstract}
The aim of this work was to evaluate the nutritive value of carob pulp for rabbits using the in vitro digestibility and gas production techniques with inocula from caecal content of rabbits. Experimental diets contained $0 \%$ (D1), $10 \%$ (D2), $20 \%$ (D3) and 100\% (D4) carob pulp on a dry matter (DM) basis and were incubated in glass syringes for $72 \mathrm{~h}$ at $39^{\circ} \mathrm{C}$. Carob pulp contained $313 \mathrm{~g}$ neutral detergent fibre/kg DM with a high acid detergent fibre (263 g/kg DM) content, resulting in a low hemicellulose content of $50 \mathrm{~g} / \mathrm{kg} \mathrm{DM}$. Potential gas production ranged from 123 (D1) to 179 (D4) mL/g DM and was similar for the D1 (123 mL/g DM), D2 (126 mL/g DM) and D3 (130 mL/g DM) treatments. The lowest $\mathrm{pH}$ value of 6.47 and the highest organic matter degradation (OMD, 64.3\%) were observed in the $100 \%$ carob pulp (D4) treatment, while its inclusion at $10 \%$ and $20 \%$ tended to improve the OMD of the diets. These results show that carob pulp is well fermented by the caecal micro-organisms of rabbits. Although its inclusion at $20 \%$ did not improve in vitro fermentation and degradation of the commercial concentrate, it was concluded that carob pulp has potential as an unconventional feed resource for rabbits. Its utilization could have a positive effect on intestinal microbiota owing to its high content of soluble fibre.
\end{abstract}

Keywords: Ceratonia siliqua, by-product, chemical composition, gas production, organic matter degradation

\# Corresponding author: azizaboubaker@yahoo.com

\section{Introduction}

Conventional by-products and unconventional materials from the food processing industry have frequently been included in livestock diets. Their utilization can have nutritional, economic and ecological advantages. The carob pod is the fruit of the carob tree (Ceratonia siliqua L.), and is mostly used in the food industry for carob bean gum and locust bean gum, which are polysaccharides in the seeds (Battle \& Tous, 1997). Nevertheless, carob pod consists mainly of pulp (90\%), which is especially rich in sugars (48\% 56\%) and in gross energy (Petit \& Pinilla, 1995), making it a high-energy feed for animal nutrition. Owing to its high content in sugars, carob pulp is very palatable. Its inclusion increases palatability (Cheeke, 1987) and reduces feeding costs in lamb fattening diets (Guessous et al., 1989; Lanza et al., 2001; Obeidat et al., 2011), but animal response is variable. In a previous experiment, average daily gain of fattening lambs was improved when carob pulp was included up to a dietary level of $30 \%$ as a substitute for citrus pulp (Guessous et al., 1988). Performance of growing calves was also improved by replacing barley with carob pulp at a dietary level of 30\% (Louca \& Papas (1973). In contrast, deleterious effects of a diet containing carob pulp were recorded on lamb growth and meat quality (Priolo et al., 2000). Bugarski et al. (1971) suggested that the incorporation of carob pulp should not exceed $10 \%$ of the diet, while Ouchkif (1988) recorded the best performance in growing lambs at an inclusion of $20 \%$. One of the main problems with the use of carob pulp in animal feeding is the presence of condensed tannins (CT). To reduce the impact of CT, Priolo et al. (2000) 
supplemented a diet based on carob pulp (56\% as fed) with $40 \mathrm{~g}$ of polyethylene glycol (PEG) per $\mathrm{kg}$ of feed. The authors found significant improvements of lamb growth and carcass and meat quality, compared with the animals fed the same diet without the addition of PEG.

Carob pulp could also be used as a supplement for rabbits. However, there are no specific studies on the optimal level of its inclusion in a practical diet. In rabbits, the caecum and proximal colon are important sites of digestion. Caecal microorganisms ferment nutrients to short-chain fatty acids (SCFA), ammonia and gases (Gidenne, 1992). In vitro gas production is used as an indicator for assessing the potential nutritive value of feedstuff for ruminants (Menke \& Steingass, 1988). This technique could also be used to characterize feed fermentation in the large intestine of non-ruminant animals (Bindelle et al., 2007).

The aim of this investigation was to study in vitro fermentation of diets containing different levels of carob pulp, using the caecal content of rabbits to evaluate its possible incorporation as an energy supplement in rabbit feed formulation.

\section{Materials and Methods}

Four diets were formulated to contain an increasing proportion of carob pulp: $0 \%, 10 \%, 20 \%$ and $100 \%$ DM for diets, D1, D2, D3 and D4, respectively, by replacing a decreasing proportion $(100 \%, 20 \%$, $10 \%$ and $0 \%$ ) of a typical commercial rabbit concentrate. Weighed feed ingredients were mixed with water to achieve a $25 \%$ - $30 \%$ moisture content, pelleted with an electric meat mincer, and oven dried at $40{ }^{\circ} \mathrm{C}$ for two days.

In vitro gas production was determined according to the Menke \& Steingass (1988) technique. Two hundred mg of sample were anaerobically incubated for 72 hours in triplicate in $100 \mathrm{~mL}$ glass syringes containing $30 \mathrm{~mL}$ of inoculum. The inoculum was prepared according to the modified method of Calabro et al. (1999). Fresh samples of caecal content were collected from eight 78-day-old New Zealand White rabbits randomly chosen prior to slaughtering. The rabbits were fed a commercial compound feed ad libitum from weaning at 35 days of age. The feed was withdrawn 12 hours before sampling, but water was still available ad libitum. After slaughtering, the caecum was isolated by tying off the two extremities with nylon string to prevent movement of digesta. Caecum content was diluted $(1: 50 \mathrm{w} / \mathrm{v})$ with the buffer solution prepared according to Menke \& Steingass (1988), and then strained through four layers of cheesecloth and held under $\mathrm{CO}_{2}$ in a water-bath at $39^{\circ} \mathrm{C}$. Syringes were pre-warmed $\left(40{ }^{\circ} \mathrm{C}\right)$ before the injection of $30 \mathrm{~mL}$ of caecal liquid per buffer mixture into each syringe, followed by incubation in a ventilated oven $\left(39 \pm 1{ }^{\circ} \mathrm{C}\right)$. Thirty min after the start of incubation the syringes were shaken gently and then every hour for the first $10 \mathrm{~h}$ of incubation. Three control syringes containing only caecal liquid and medium (buffer) were used as blanks, so that the gas produced by caecal contents without substrate could be subtracted from the total gas production. The production of gas resulting from microbial fermentation was measured manually at the following intervals: 0, 2, 4, 6, 8, 10, 12, 24, 36, 48 and 72 hours.

At the end of fermentation, the $\mathrm{pH}$ of the fermented solution in each syringe was recorded using a $\mathrm{pH}$ meter, and syringes were removed from the oven and put in a refrigerator at $4{ }^{\circ} \mathrm{C}$. The solid and liquid matter in each syringe were separated by filtration using a vacuum pump. The dry matter (DM) degraded, was measured after drying at $100{ }^{\circ} \mathrm{C}$ until a constant weight was obtained. The organic matter (OM) degraded, was measured after ashing $\left(6 \mathrm{~h} / 500^{\circ} \mathrm{C}\right)$. Incubations were repeated three times.

Samples were analysed for DM, OM, nitrogen (N) and crude fibre (CF) according to AOAC (1990). Neutral detergent fibre (NDF) and acid detergent fibre (ADF) were determined according to the procedure of Van Soest et al. (1991). Hemicellulose (HC) and neutral detergent soluble (NDS) were calculated according to the equations:

$\mathrm{HC} \%=\mathrm{NDF} \%-\mathrm{ADF} \%$ and NDS $\%=100 \%-\mathrm{NDF} \%$; respectively.

Results were analysed (ANOVA) using the generalized linear model procedure (SAS, 1988) with the diets as the treatment factor based on the following statistical model:

$\mathrm{Yij}=\mu+\mathrm{Ti}+\mathrm{eij}$,

where Yij is a dependent variable (gas production, $\mathrm{pH}$ and $\mathrm{OMD}$ ), $\mu$ is the population mean, Ti is a diet and eij is the residual error. The means were compared by Scott-Knott test at a probability level of 5\%. 


\section{Results and Discussion}

Table 1 shows the chemical composition of the experimental diets, which were previously used for an in vivo trial (Gasmi-Boubaker et al., 2007). The low CP content (64 g/kg DM) of carob pulp is comparable with values reported in the literature (Albanell et al., 1991; Petit \& Pinilla, 1995; Williams et al., 2005). The ADF content of carob pulp (263 g/kg DM) was higher at than the $170 \mathrm{~g} / \mathrm{kg}$ and lower than the $290 \mathrm{~g} / \mathrm{kg}$, the range recommended by Gidenne (2003) to prevent digestive troubles in the growing rabbit. This author observed that the sanitary risk (SR = mortality + morbidity) increased from $18 \%$ to $28 \%$ when the dietary ADF content decreased from $19 \%$ to $15 \%$.

An examination of carob pulp showed that NDF and ADF values are very close, resulting in a low HC content $(50 \mathrm{~g} / \mathrm{kg} \mathrm{DM})$, when the HC fraction is calculated as the difference between NDF and ADF values. In this study, the analytical method to measure ADF concentration might have caused some kind of polymerization of sugars with the fibre fraction, resulting in an artificial increase in apparent ADF content, and thus underestimating the HC value. Although this method is not biochemically valid for estimating hemicellulose, this is the only available approach for a routine laboratory analysis of feed ingredients. This problem is demonstrated in a study by Milad et al. (2010) on kibbled carob pods. They, surprisingly, reported that the content of $\mathrm{ADF}$ was greater than that of NDF, and that the HC content was negative.

There has been recent interest in the role of soluble fibre in rabbit feeding owing to alleged positive effects on digestive health of rabbits. As can be seen in Table 1, the NDS proportion was higher in carob pulp (687 g/kg DM) than in treatments D1 (548 g/kg DM), D2 (563 g/kg DM) and D3 (578 g/kg DM). The utilization of this by-product as a nutrient source for rabbit could therefore have a positive effect on intestinal microbiota. It was reported that the most important properties of soluble fibre are its higher fermentability and its capacity to increase viscosity in the digestive tract (Rodriguez-Romero et al., 2011).

Table 1 Diet formulation and chemical composition of diets incorporating 0\%, (D1), 10\% (D2), 20\% (D3) and $100 \%$ (D4) carob pulp

\begin{tabular}{lrrrr}
\hline & \multicolumn{3}{c}{ Diets } \\
\cline { 2 - 4 } & D1 & D2 & D3 & D4 \\
\hline Ingredients (\%) & & & & \\
$\quad$ Commercial concentrate & 100 & 90 & 80 & 0 \\
$\quad$ Carob pulp & 0 & 10 & 20 & 100 \\
$\quad$ Total & 100 & 100 & 100 & 100 \\
Chemical composition (g/kg DM) & & & & \\
$\quad$ Dry matter & 882 & 909 & 891 & 917 \\
Organic matter & 907 & 164 & 159 & 957 \\
Crude protein (N $\times$ 6.25) & 169 & 202 & 198 & 135 \\
Crude fibre & 210 & 437 & 424 & 313 \\
$\quad$ Neutral-detergent fibre & 451 & 223 & 227 & 263 \\
Acid-detergent fibre & 218 & 214 & 197 & 50 \\
Hemicellulose & 233 & 563 & 578 & 687 \\
Neutral detergent soluble & 548 & & \\
\end{tabular}

Table 2 shows means of $\mathrm{pH}$, total gas production and OM degraded for the experimental diets after 72 $\mathrm{h}$ of fermentation in vitro. Overall, gas production ranged from 123 to $179 \mathrm{~mL} / \mathrm{g} \mathrm{DM}$ and did not differ $(P>0.05)$ between D1, D2 and D3. In accordance with published results, it could be suggested that the highest amount and the majority of gas produced from carob pulp (D4) derived from sugars (glucose and saccharose), which are important components of carob pulp. Thomson (1971) investigated 40 cultivars of carob pods and observed high levels of sugars, ranging from $37 \%$ to $62 \%$. These soluble carbohydrates are readily degraded by gut microorganisms. In rabbits, caecal micro-organisms ferment available nutrients, 
mainly polysaccharides, to short-chain fatty acids, ammonia and gases. The amount of gas produced in in vitro fermentation is directly related to the amount of SCFA production (Getachew et al., 1998). Consequently, results presented in Table 2 suggest that large amounts of SCFA will be produced with consequent reduction of caecal $\mathrm{pH}$ when carob pulp is fermented.

Table 2 Mean $( \pm \mathrm{SE}) \mathrm{pH}$, gas production $(\mathrm{mL} / \mathrm{g} \mathrm{DM})$ and organic matter $(\mathrm{OM})$ degraded (expressed as \%) of diets incorporating different levels of carob pulp after $72 \mathrm{~h}$ of fermentation in vitro

\begin{tabular}{|c|c|c|c|}
\hline Diets & $\mathrm{pH}$ & $\begin{array}{c}\text { Gas } \\
\text { (mL/g DM) }\end{array}$ & $\begin{array}{c}\text { OM degraded } \\
(\%)\end{array}$ \\
\hline D1 (0\% carob pulp) & $6.65^{\mathrm{a}} \pm 0.08$ & $123^{\mathrm{b}} \pm 22$ & $58.58^{\mathrm{b}} \pm 3.70$ \\
\hline D2 (10\% carob pulp) & $6.66^{\mathrm{a}} \pm 0.03$ & $126^{\mathrm{b}} \pm 12$ & $60.39^{\mathrm{b}} \pm 4.43$ \\
\hline D3 (20\% carob pulp) & $6.64^{\mathrm{a}} \pm 0.04$ & $130^{b} \pm 26$ & $62.01^{\mathrm{b}} \pm 4.17$ \\
\hline D4 (100\% carob pulp) & $6.47^{\mathrm{b}} \pm 0.07$ & $179^{a} \pm 24$ & $64.27^{\mathrm{a}} \pm 3.46$ \\
\hline Probability. & $<0.001$ & 0.007 & 0.043 \\
\hline
\end{tabular}

The variation in in vitro fermentation may be related to differences in chemical composition of the diets. Abreu \& Bruno-Soares (1998) found a positive correlation between gas production and the OMD $(r=0.69 ; P<0.05)$. Of all diets, carob pulp (D4) had a higher $(P<0.05)$ in vitro OM matter degradation (64.3\%) than the D1 (58.6\%) treatment, while that in D2 (60.3\%) and D3 (62\%) were similar $(P>0.05)$ to $\mathrm{D} 1$. The OMD of carob pulp is in accordance with the in sacco degradation of DM (65.4\%) (Albanell et al., 1991). An in vivo trial (Gasmi-Boubaker et al., 2007) showed that the addition of carob pulp to the diet consumed by rabbits tended to improve DM and OM digestibility with increasing the level of carob pulp in the diet.

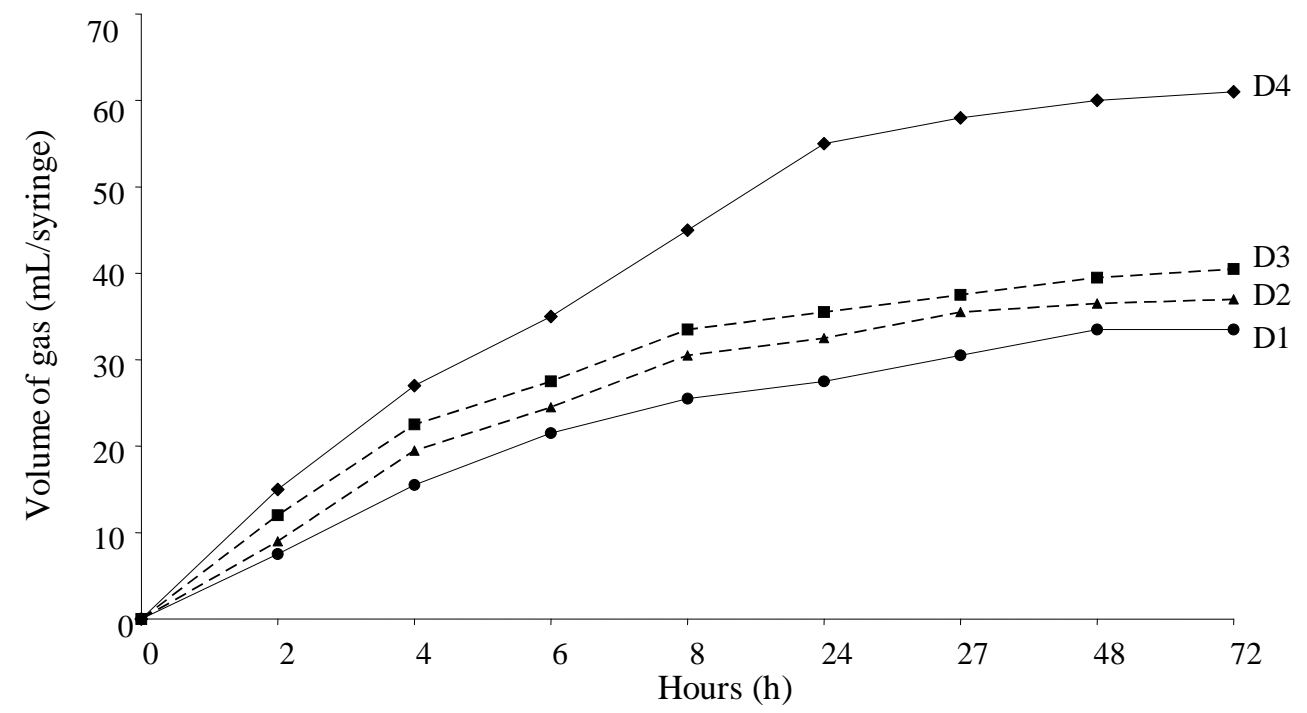

Figure 1 Gas production profile of diets incorporating 0\% (D1), 10\% (D2), 20\% (D3) and 100\% (D4) carob pulp and incubated with inoculum from rabbit caecum.

On the basis of both gas production and OMD, the feed classification is $\mathrm{D} 1<\mathrm{D} 2<\mathrm{D} 3<\mathrm{D} 4$. As stated by Bindelle et al. (2007), the ranking of in vitro fermentative characteristics of substrates would probably 
remain the same as in in vivo, even if the diversity of various conditions cannot be fully reproduced by in vitro methods. However, under practical conditions, higher microbial fermentation of carob pulp might imply high energy losses. Moreover, and owing to its low CP content, the administration of carob pulp as a single ingredient would not be recommended, because additional protein supplementation is required.

In vitro gas production can reflect the extent to which substrates are fermented by gut microorganisms (Schofield, 2000). The trend of gas production is well described by Figure 1. It demonstrates the difference in cumulative gas production between D1, D2, D3 and D4. The plateau of the curves was reached at $72 \mathrm{~h}$ and the initial phase of fermentation was short and does not differ between the four diets. It is speculated that before fermentation started, the time needed for hydration was short and the microbial colonization was very quick. After 2 hours and during $72 \mathrm{~h}$ of incubation, carob pulp (D4) produced the highest volume of gas compared with D1, D2 and D3. It is reasonable to expect such a trend when carob pulp is incubated alone, because this by-product is rich in sugars and NDS. Sugars are positively correlated with the maximum volume of gas produced at t (Piquer et al., 2009), and ferment more quickly than starch and much quicker than cellulose and hemicellulose (Sniffen et al., 1992). Diets incorporating of 0\%, $10 \%$ and $20 \%$ carob pulp would have a much lower content of sugars and NDS. Therefore, total potential gas productions would also be lower.

\section{Conclusion}

Carob pulp is highly fermented by the caecal micro-organisms of rabbits. Although, its inclusion at $20 \%$ did not significantly improve in vitro fermentation and degradation of the commercial concentrate, it can be concluded that carob pulp has potential as an unconventional feed resource for rabbits. Its utilization could have a positive effect on intestinal microbiota owing to its high content in soluble fibre.

\section{Acknowledgements}

This study was funded by the Ministry of Scientific Research, Technology and Capacity Building of Tunisia (Laboratoire de Recherche en Economie et Technologie Agro-Alimentaire, INAT).

\section{References}

Abreu, J.M.F. \& Bruno-Soares, A.M., 1998. Chemical composition, organic matter digestibility and gas production of nine legume grains. Anim. Feed. Sci. Technol. 70, 49-57.

Albanell, E., Caja, G. \& Plaixats, J., 1991. Characteristics of Spanish carob pods and nutritive value of carob kibbles. Options Méditerranéennes-Séries séminaires- n 16: 135-136.

AOAC, 1990. Association of Official Analytical Chemists, Official Methods of Analysis (15th ed.), AOAC, Arlington, VI, USA.

Batlle, J. \& Tous, 1997. Carob tree (Ceratonia siliqua L.), Promoting the conservation and use of underutilized and neglected crops.17, Institute of Plant Genetics and Crop Plant Research, Gatersleben/International Plant Genetics Resources Institute, Rome.

Bindelle, J., Buldgen, A., Lambotte, D., Wavreille, J. \& Leterme, P., 2007. Effect of pig faecal donor and pig diet composition on in vitro fermentation of sugar beet pulp. Anim. Feed Sci. Technol. 132, 212-226.

Bugarski, D., Dzimic, M. \& Bukojevic, J., 1971. The carob fruit (Ceratonia siliqua), its composition, nutritive value and possibility of its use in the diet of farm animals. Vet. Yugoslavia 20, 547.

Calabro, S., Nizza, A., Pinna, W., Cutrignelli, M. \& Piccolo, V., 1999. Estimation of digestibility of compound diets for rabbits using the in vitro gas production technique. Wrld Rabbit Sci. 7, 97-201.

Cheeke, P.R., 1987. Rabbit Feeding and Nutrition. Academic Press, Inc. London.

Gasmi-Boubaker, A., Bergaoui, R., Khaldi, A., Mosquera-Losada, M.R. \& Ketata, A., 2007. First attempt to study carob pulp utilization in rabbits feeding. J. Anim. Vet. Adv. 6, 1269-1272.

Getachew, G., Blümmel, M., Makkar, H.P.S. \& Becker, K., 1998. In vitro gas measuring techniques for assessment of nutritional quality of feeds: a review. Anim. Feed Sci. Technol. 72, 261-281.

Gidenne, T., 1992. Effect of fibre level, particle size and adaptation period on digestibility and rate of passage as measured at the ileum and in the faeces in the adult rabbit. Br. J. Nutr. 67, 133-146. 
Gidenne, T., 2003. Fibres in rabbit feeding for digestive troubles prevention: respective role of low-digested and digestible fibre. Livest. Prod. Sci. 81, 105-117.

Guessous, F., E1 Hilali, A. \& Johnson, W.L., 1988. Influence du taux d'incorporation de la pulpe de caroube sur la digestibilité et l'utilisation des rations par les ovins à l'engraissement. Reprod. Nutr. Dcv. 28, 93.

Guessous, F., Rihani, N., Kabbali, A. \& Johnson, W.L., 1989. Improving feeding systems for sheep in a Mediterranean Rain-Fed Cereals/Livestock Area of Morocco. J. Anim. Sci. 67, 3080-3086.

Lanza, M., Priolo, A., Biondi, L., Bella, M. \& Ben Salem, H., 2001. Replacement of cereal grains by orange pulp and carob pulp in faba bean-based diets fed to lambs: effects on growth performance and meat quality. Anim. Res. 50, 21-30.

Louca, A. \& Papas, A., 1973. The effect of different proportions of carob pod meal in the diet on the performance of calves and goats. Anim. Prod. 17, 139.

Menke, K.H. \& Steingass, H., 1988. Estimation of the energetic feed value obtained from chemical analysis and in vitro gas production using rumen fluid. Anim. Res. Dev. 28, 7-55.

Milad, S., Rymer, C. \& Radley, R., 2010. Effects of ammonia treatment and undegradable protein supplementation on nutrient digestion of sheep fed on wheat straw based diets. Archiva Zootechnica pp. 39-46.

Obeidat, S., Alrababah, A., Abdullah, Y., Alhamad, N., Gharaibeh, A., Rababah, M. \& Abu Ishmais, A., 2011. Growth performance and carcass characteristics of Awassi lambs fed diets containing carob pods (Ceratonia siliqua L.). Small Rumin. Res. 96, 149-154.

Ouchkif, M., 1988. Influence d'incorporation de proportions différentes de pulpe de caroube sur la digestibilitd ct l'utilisation de la ration par les agncanx t l'engraissement. Memoire de 3eme cycle Agron. Hassan II Inst.Agron. Vet., Rabat, Morocco.

Petit, M. \& Pinilla, M., 1995. Production and purification of a sugar syrup from carob pods. Lebensm. Wiss. u. Technol. 28, 145-152.

Piquer, O., Casado, C., Biglia, S., Fernández, C. \& Blas, E., 2009. In vitro gas production kinetics of whole citrus fruits. Anim. Feed Sci. 18, 745-757.

Priolo, A., Waghorn, G.C., Lanza, M., Biondi, L. \& Pennisi, P., 2000. Polyethylene glycol as a means for reducing the impact of condensed tannins in carob pulp: effects on lamb growth performance and meat quality. J. Anim. Sci. 78, 810-816.

Rodríguez-Romero, N., Abecia, L. \& Fondevila, M., 2011. Effects of levels of insoluble and soluble fibre in diets for growing rabbits on faecal digestibility, nitrogen recycling and in vitro fermentation. Wrld Rabbit Sci. pp. 85-94.

Schofield, P., 2000. Gas production (Chapter 10). In: Farm Animal Metabolism and Nutrition. Ed. D’Mello, J.P.F., CABI publishing, UK. 450 pp.

Sniffen, C.J., O’Connor, J.D., Van Soest, P.J., Fox, D.G. \& Russel, J.B., 1992. A net carbohydrate and protein system for evaluating cattle diets. II Carbohydrate and protein availability. J. Anim. Sci. 70, 3562-3577.

SAS, 1988. Statistical Analysis Systems Institute SAS/STAT user's guide, release 6.03 edition. SAS Institute, Cary, N.C., USA.

Thomson, P., 1971.The carob in California. California Rare Fruit Growers. Year Book, III: pp. 61-102.

Van Soest, P., Robertson, J. \& Lewis, B.A., 1991. Methods for dietary fibre, neutral detergent fibre, and nonstarch polysaccharides in relation to animal nutrition. J. Dairy Sci. 74, 3583-3597.

Williams, B., Bosh, M., Boer, H., Verstegen, M. \& Tamminga, S., 2005. An in vitro batch culture method to assess potential fermentability of feed ingredients for monogastric diets. Anim. Feed Sci. Technol. 123-124, 445-462. 